\begin{tabular}{lll} 
ORIGINAL RESEARCH PAPER & General Medicine \\
\cline { 3 - 3 } & &
\end{tabular}

\title{
Dr. Krushna
}

Chandra

M.D (Medicine) Intensivist, D.H.H.Malkangiri, Odisha.

\section{Mohapatra}

\section{Dr. Nihar Ranjan Tripathy*}

\section{M.D (Anesthesiology),D.H.H. Malkangiri, Odisha. *Corresponding Author}

Globe is going through a never seen devastating pandemic of COVID-19 since December, 2019. Now, after a span of six months, COVID-19 is no more new and many characteristics of the virus, it's path physiology, clinical features, disease progression and management came forth. This is truly remarkable and we salute to the global fraternity. We learnt a many. Disease course is defined as of continuous 10 days, if everything else is normal. Third to eighth day is the defined risk period and ninth to twelfth day is the period of deterioration in symptomatic. Symptoms developing after 21 days defined to be recurrence and no such definite incidents is yet detected. To the contrary of all the cases we find in our day to day practice in different COVID centers, here is an anecdote case report of an elderly doctor with two definitive peaks of symptoms within the defined disease course of 10 days, which is unique and not reported elsewhere till date. Sore, wet and tingling nose along with night sweat with or without fever are the earliest and most consistent features of covid-19 as we found in this case report and later confirmed by analyzing in all other cases where most of the cases reported these symptoms.

\section{INTRODUCTION:}

Globe is going through a never seen devastating pandemic of COVID-19 since December, 2019.The novel corona virus 2019 (COVID-19) also known as severe acute respiratory syndrome corona virus Two (SARS-CoV-2) is an envelope, non-segmented positive-sense RNA virus belonging to the beta-coronaviridae family. ${ }^{[1]}$ More than 17 Million cases of 213 countries with death over 672 Lakhs are reported till date. ${ }^{[2]}$ India presents currently the highest numbers of confirmed COVID-19 cases in Asia. ${ }^{[3,4]}$ and has the third highest number of confirmed cases in the world after the United States and Brazil. ${ }^{[3,4]}$ Odisha, a state in the east cost of India has confirmed 54,630 cases and 324 deaths as of $14^{\text {th }}$ Aug $2020 .^{[5]} \mathrm{We}$ contributed 1083 cases and two deaths to this tally by $14^{\text {th }}$ Aug $2020 .^{[5]}$

To the contrary of all the cases we find during our clinical practice in the COVID centers, here is an anecdote case report, where in the disease course of 10 days it has been found two peaks in symptoms. Such a disease course is nowhere described till date. It requires further study which may better define the disease course and may help clinicians for cautionary discharge from Covid care pathway, as there are many anecdotal evidences of death following discharge from hospitals.

One such case of an elderly doctor detected positive for COVID-19 in our Covid center. Second peak of symptoms were noticed and were analyzed in the context of COVID-19 differentiating from other possibilities.

\section{Case presentation:}

61 year old male doctor, a dedicated COVID-19 warrior having multiple contacts with COVID-19 patients during his work without appropriate PPE, presented to OPD of Covid-19 hospital, Malkangiri with fever and dry cough for two days.

He was having low grade fever with night sweat, and generalized body ache, without chills and rigor. Fever was associated with infrequent dry cough. Nasal cavity was sore, irritating and wet, remarkably without running nose, or anosmia. A known case of asymptomatic hypertrophic cardiomyopathy since more than 10 years and was on metoprolol. Also a comorbidity of Asthma-COPD overlapping Syndrome (ACOS) was there and the patient was |www.worldwidejournals.com on irregular salbutamol MDI with a history of smoking 20 years back.

On presentation he was having a temperature of $101^{\circ} \mathrm{F}$, blood pressure $110 / 70 \mathrm{~mm} \mathrm{Hg}$, heart rate of 79 beats per minute, respiratory rate of 24 per minute, and oxygen saturation of $97 \%$ on room air which was detected to be $96 \%$ after a six minutes' walk test. Physical examination showed no other significant cardiovascular, respiratory or central nervous system findings except a chesty dry cough. His laboratory investigations are shown in Table 1.

He was tested positive for COVID-19 by rapid antigen test (RAT) and was confirmed by RT-PCR on 31st July (Day One). As per hospital protocol of therapy, he was started with vitamin C, B complex, zinc and levocloperasteine. Initial routine clinical findings showed X-ray features of bilateral hilar blurring and Kerley-A lines in left lung implying interstitial edema (figure 1).To the existing regimen oral Azithromycin $500 \mathrm{mg}$ once daily for five days and Co-amoxyclav $625 \mathrm{mg}$ three times daily for seven days was added.

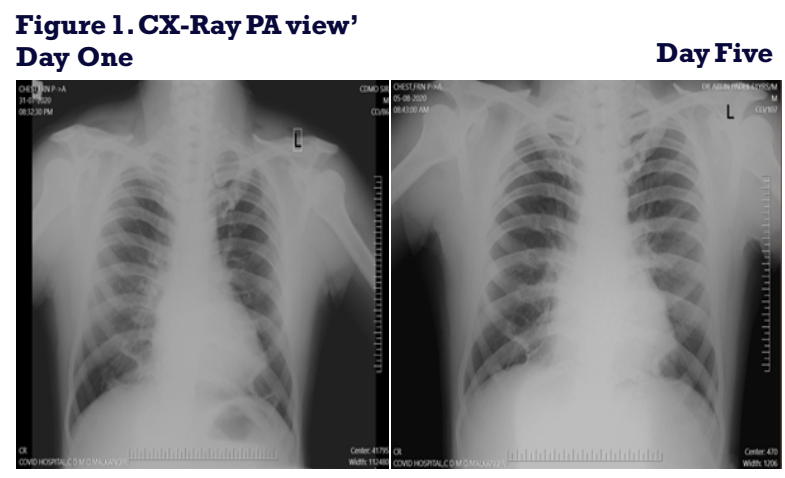

Table 1.Laboratory investigations

\begin{tabular}{|l|l|l|l|l|}
\hline \multirow{2}{*}{$\begin{array}{l}\text { Laboratory } \\
\text { investigations }\end{array}$} & \multicolumn{4}{l}{ Parameters } \\
\cline { 2 - 5 } & Day - l & Day -3 & Day - 6 & Day - 9 \\
\hline Hemoglobin & $14 \cdot 80 \mathrm{~g} / \mathrm{dl}$ & $15 \cdot 00 \mathrm{~g} / \mathrm{dl}$ & $15.00 \mathrm{~g} / \mathrm{dl}$ & $13.00 \mathrm{~g} / \mathrm{dl}$ \\
\hline Lymphocytes & $1 \cdot 2010^{9} / 1$ & $2 \cdot 0010^{9} / 1$ & $2 \cdot 0010^{9} / 1$ & $1.6010^{9} / 1$ \\
\hline $\begin{array}{l}\text { TotalLeukocyte } \\
\text { Count }\end{array}$ & $7 \cdot 3010^{9} / 1$ & $6.0010^{9} / 1$ & $5.6010^{9} / 1$ & $5.4010^{9} / 1$ \\
\hline
\end{tabular}




\begin{tabular}{|l|l|l|l|l|}
\hline ESR & $\begin{array}{l}15 \cdot 00 \mathrm{~mm} / \mathrm{l}^{\mathrm{st}} \\
\mathrm{hr}\end{array}$ & $\begin{array}{l}12 \cdot 00 \\
\mathrm{~mm} / \mathrm{l}^{\mathrm{st}} \mathrm{hr}\end{array}$ & $\begin{array}{l}27 \cdot 00 \mathrm{~mm} / \\
\mathrm{l}^{\text {st }} \mathrm{hr}\end{array}$ & $\begin{array}{l}72 \cdot 00 \\
\mathrm{~mm} / \mathrm{l}^{\text {st }} \mathrm{hr}\end{array}$ \\
\hline CRP & $0 \cdot 10 \mathrm{mg} / \mathrm{dl}$ & $\begin{array}{l}0 \cdot 10 \\
\mathrm{mg} / \mathrm{dl}\end{array}$ & $\begin{array}{l}2 \cdot 00 \\
\mathrm{mg} / \mathrm{dl}\end{array}$ & $\begin{array}{l}3 \cdot 30 \\
\mathrm{mg} / \mathrm{dl}\end{array}$ \\
\hline $\begin{array}{l}\text { Platelet } \\
\text { Count }\end{array}$ & $165 \cdot 0010^{9} / \mathrm{l}$ & $\begin{array}{l}116 \cdot 00 \\
10^{9} / \mathrm{l}\end{array}$ & $\begin{array}{l}104 \cdot 00 \\
/ 1\end{array}$ & $\begin{array}{l}114 \cdot 00 \\
10^{9} / 1\end{array}$ \\
\hline $\begin{array}{l}\text { Random } \\
\text { Plasma } \\
\text { Glucose }\end{array}$ & $128 \cdot 00 \mathrm{mg} / \mathrm{dl}$ & $\begin{array}{l}74 \cdot 70 \\
\mathrm{mg} / \mathrm{dl}\end{array}$ & $\begin{array}{l}102 \cdot 00 \\
\mathrm{mg} / \mathrm{dl}\end{array}$ & - \\
\hline Serum Urea & $30 \cdot 20 \mathrm{mg} / \mathrm{dl}$ & - & $\begin{array}{l}31 \cdot 60 \\
\mathrm{mg} / \mathrm{dl}\end{array}$ & - \\
\hline $\begin{array}{l}\text { Serum } \\
\text { Creatinine }\end{array}$ & $1 \cdot 10 \mathrm{mg} / \mathrm{dl}$ & - & $\begin{array}{l}1 \cdot 00 \\
\mathrm{mg} / \mathrm{dl}\end{array}$ & - \\
\hline $\begin{array}{l}\text { Serum } \\
\text { Sodium }\end{array}$ & $138 \cdot 00$ & $\begin{array}{l}141 \cdot 60 \\
\mathrm{mmol} / 1\end{array}$ & $\begin{array}{l}141 \cdot 40 \\
\mathrm{mmol} / 1\end{array}$ & - \\
\hline $\begin{array}{l}\text { Serum } \\
\text { Potassium }\end{array}$ & $4 \cdot 80 \mathrm{mmol} / \mathrm{l}$ & $4 \cdot 59$ & $\begin{array}{l}4 \cdot 80 \\
\mathrm{mmol} / 1\end{array}$ & - \\
\hline $\begin{array}{l}\text { Total } \\
\text { Bilirubin }\end{array}$ & $0 \cdot 40 \mathrm{mg} / \mathrm{dl}$ & - & $\begin{array}{l}0 \cdot 40 \\
\mathrm{mg} / \mathrm{dl}\end{array}$ & - \\
\hline $\begin{array}{l}\text { Direct } \\
\text { Bilirubin }\end{array}$ & $0 \cdot 20 \mathrm{mg} / \mathrm{dl}$ & - & $\begin{array}{l}0 \cdot 20 \\
\mathrm{mg} / \mathrm{dl}\end{array}$ & - \\
\hline PT & $9 \cdot 18 \mathrm{Sec}$ & - & $7 \cdot 92 \mathrm{Sec}$ & $15 \cdot 57 \mathrm{Sec}$ \\
\hline INR & $0 \cdot 63$ & - & $0 \cdot 53$ & $1 \cdot 17$ \\
\hline APTT & $25 \cdot 00 \mathrm{Sec}$ & - & $21.70 \mathrm{Sec}$ & $43 \cdot 70 \mathrm{Sec}$ \\
\hline
\end{tabular}

On third day of persistent symptoms he was started with Favipiravir 1400mg two times daily on day one and there after followed by $600 \mathrm{mg}$ two times daily. His fever subsided on sixth day. Cough was infrequent. On the seventh day expectorated sputum was tested for COVID-19 and found negative both in RAT and CBNAAT. The blood parameters were also normal. Co-amoxyclav was discontinued.

After Two days that was on day nine, his fever recurred and rose to $102^{\circ}$ Fahrenheit which was more than the maximum temperature attained in the first peak. It was with increased frequency of dry cough associated with wheezing. $\mathrm{SpO}_{2}$ and exertional $\mathrm{SpO}_{2}\left(\mathrm{eSpO}_{2}\right)$ were $96 \%$ and $94 \%$ respectively. On that day (Day 9) ESR was $72 \mathrm{~mm}$ lsthr. CRP level was increased to $33 \mathrm{mg} / \mathrm{dl}$. He was under no medication. Favipiravir was discontinued after day Seven. Naso-pharyngeal swab was positive for COVID-19 both in RAT and cartridge based nucleic acid amplification test (CBNAAT). He was tested for Ddimer, Pro-calcitonin, anti-pro-BNP and TROP-I and all were found to be in normal range. ECG demonstrated dynamic ST-T changes.

He was subjected to CT thorax and the findings suggested patchy peripheral ground glass opacity and septal thickening in bilateral upper and lower lobe (figure 2). Subsequently he was evaluated and differentiated from CAD (Coronary artery disease), HCM (Hypertrophic cardiomyopathy) and secondary infection in ACOS. Therapy instituted were clopidogrel, atorvastatin, MDI budesonide and MDI levosalbutamol. On the 14th day his fever was subsided and cough was present but recovered enough for undisturbed sleep. For continuous seven days, he was monitored for $\mathrm{SpO}_{2}$ and $\mathrm{SpO}_{2}$ which were $98 \%$ and $97 \%$ respectively. On 22 nd day he was tested for RAT and CBNAAT and both the test reported negative for Covid-19 and the patient was clinically asymptomatic hence was released from Covid care pathway.

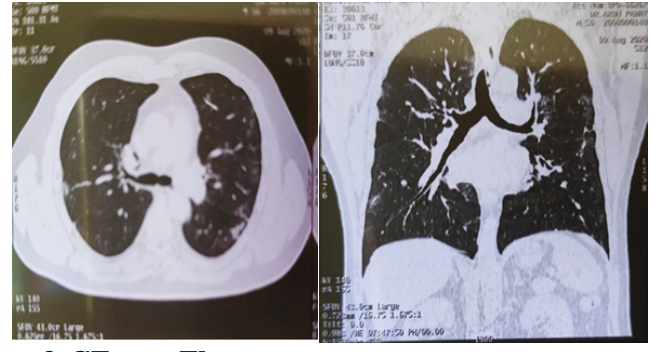

Figure 2. CT scan Thorax

\section{Interpretation:}

Double peak in symptomatology is possible in COVID-19, with a short remission in between. Study may mandate for the pathophysiologic basis of these peaks which may help in planning and better management. This anecdote is a prototype of many undocumented cases where consistent presence of sore, wet, tingling nasal vestibule was noted. This is exceptional in comparison to running nose and sneezing in common flu. Leading questions only can elicit this symptom. The second clinical symptom we would like to highlight is the symptom of night sweat with or without fever as was seen in this case. These two unreported and ignored symptoms helped us in prompt clinical suspicion of covid-19. We have admitted more than 300 patients in the different COVID-19 centers and did contact tracing of more than 700 patients in home isolation in our district. Surprisingly we detected most of our patients with these two atypical symptoms of sore, wet, tingling nasal vestibule and night sweat with or without fever which no one consider to be symptoms as per guidelines and now we are analyzing their data for further study

Further deep we learnt that the two above mentioned atypical symptoms were very much there to whom colloquies leveled as asymptomatic in tracing. In a number of all those found COVID-19 positive in contact tracing (unpublished study by us) and manifested symptoms after some days (what is known as pre-symptomatic), these two atypical symptoms were manifested earlier and went unrecognized. This confirms double peak of our anecdote where two peaks are perceptible and sore, wet, tingling nasal vestibule and night sweat with or without fever are the first peak and perceptible symptoms are the second peak.

We as a protocol defined incubation period of 10 days from the day of contact with the primary case. In $36 \%$ of those traced sore, wet, tingling nasal vestibule and night sweat with or without fever were noticed around two to three days from the day of contact.

\section{CONCLUSION:}

Sore, wet and tingling nose along with night sweat with or without fever are the earliest and most consistent features of covid-19 as we found in this case report and later confirmed by analyzing in all other cases where most of the cases reported these symptoms. Double peak is the norm rather exception on covid-19. Contact tracer's leading interrogation can elicit these earlier primary symptoms and can help early detection and containment of the spread. It requires further studies to support our findings.

\section{Conflicts of interest: None}

Funding resource: None

\section{REFERENCES:}

1. Alshami A, Douedi S, Varon J. Coronavirus in the arena: one more time. Curr Resp Med Rev 2020;16:1.

2. WHO Coronavirus Didease (COVID-19) Dashboard. Retrieved 24th May 2020.

3. "India most infected by Covid-19 among Asian countries, leaves Turkey behind". Hindustan Times. 29 May 2020. Retrieved 30 May 2020.

4. WHO Coronavirus Didease (COVID-19) Dashboard. Retrieved 13 August 2020.

5. "Home | Ministry of Health and Family Welfare | GOI". mohfw.gov.in. Retrieved 14 August 2020 